\title{
Laboratory Investigation of Inorganic Fouling of Low Pressure UV Disinfection Lamps
}

\author{
M. SHERIFF AND R. GEHR*
}

Department of Civil Engineering \& Applied Mechanics, McGill University, Montreal, Quebec H3A $2 K 6$

Iron(III) (mainly dosed as $\mathrm{FeCl}_{3}$ ) is one of the main inorganic constituents associated with the fouling of UV lamps during disinfection of wastewater. A low pressure mercury lamp UV system was operated under laboratory conditions to assess the effects of heat and UV light on fouling. Iron(III) was dosed at different concentrations and fouling was monitored by measuring the UV irradiance. The potential for ferric phosphate fouling and the effects of organics were also studied.

Results showed that fouling did not occur in recirculating systems over 12 days of observation. However, in flow-through systems, the extent and rate of fouling depended on the solution Fe concentration. Furthermore, addition of phosphorus increased the fouling rate. Bulk precipitation appeared to be significant at iron(III) dosing over $3 \mathrm{mg} / \mathrm{L}$.

Theoretical predictions of an equilibrium model (MINEQL ${ }^{+}$) showed similar trends with measured concentrations of soluble Fe and $P$ from batch tests. However, model predictions of temperature effects alone could not account for the observed solids deposition on the quartz sleeve. Bulk precipitation, followed by sedimentation, was considered to be the dominant mechanism at high iron (III) concentrations.

Key words: iron (III), phosphate, precipitation, fouling, UV irradiance

\section{Introduction}

Ultraviolet (UV) radiation, based on low-pressure lamps employing a modular, open-channel configuration, has gained widespread use for disinfecting wastewater in North America. The process is simple to operate and there has been no evidence of toxic byproducts (WEF 1996). Also, the mechanism of the disinfection process is well understood and documented. However, accumulation of solids on the quartz sleeve (enclosing the lamps) represents a major limitation on the use of low-pressure lamps. Fouling of the quartz sleeve acts to reduce the irradiance of UV light received by the microorganisms, resulting in reduced disinfection efficiency. When new and clean, the quartz sleeve has a transmittance of 90 to $95 \%$ (EPA 1986; Harris et al. 1987), but transmittance is considerably reduced over time with material accumulation on its surface. This necessitates cleaning, which is accomplished by a variety of methods: mechan- 
ical (wipers), ultrasonic transducers, high pressure spray nozzle and/or manual cleaning (using detergents, alcohol and/or other chemicals).

The phenomenon of fouling is widely recognized and much literature on the subject has been published. Fouling is believed to be the result of a combination of hydraulics, heat and water quality effects. While Diamant (1996) considered fouling to be a settling and accumulating process, Cairns (1996) proposed fouling to be a net process of loading and removal of UV absorbing organics and/or inorganics present in the wastewater and suggested adsorption as one mechanism of fouling. The channel walls and lamps have been shown to induce a shearing or sloughing action, which tends to increase with increase in fluid velocity (Blatchley et al. 1995). This therefore requires determination of the critical shear stress for film formation as well as for sloughing. In a pilot experiment, sloughing action was found to be significant at hydraulic loadings over 2 L/s-lamp (Jesien 1998).

As with heat exchangers, there is reason to believe that heat transfer from the lamp may be sufficient to induce precipitation of dissolved substances at the quartz-water interface. However, Aarts (1997) reasoned that heat generated by a single low-pressure lamp may not be significant, considering the low power input (around 40 to $90 \mathrm{~W}$ ) and the cooling effect of the flowing liquid. Despite the foregoing, it is not unreasonable to assume the existence of a laminar boundary layer at the quartz-water interface where heat-induced precipitation could be significant (Lin et al. 1999).

Several attempts have been made to link fouling with water quality characteristics and it has been found that the incidence of fouling and its composition are site specific, and vary from plant to plant. Fouling has been associated with high hardness and/or waters having high grease and oil content (EPA 1986; Diamant 1996), a variety of multi-cationic species such as Ca, Mg, Al, Fe (Harris et al. 1987; Perrot and Baron 1995; Blatchley et al. 1996; Jesien 1998) and the presence of microorganisms (Gschlößl 1994). In particular, there is indication that the fouling rate is governed by Fe concentrations. Gehr et al. (1993) showed that high Fe concentrations, especially in plants using physicochemical treatment, can promote accelerated fouling. Furthermore, it was shown that Fe levels in excess of $0.5 \mathrm{mg} / \mathrm{L}$ can affect the disinfection process and accelerate fouling of the UV lamps (Gehr and Wright 1998). However, little is known about the mechanism or what initiates the fouling process.

A laboratory study was therefore undertaken to investigate the occurrence of heat-induced precipitation of dissolved $\mathrm{Fe}$. Fe, commonly dosed as $\mathrm{FeCl}_{3}$, is used for lowering of turbidity, odour control, as a filter aid (Soroushian et al. 1996), and also in phosphorus removal (Jenkins and Hermanowicz 1991; James et al. 1996). The high levels of $\mathrm{FeCl}_{3}$ employed may result in increased iron levels in the secondary effluent and may impact upon the UV disinfection process. Soroushian et al. (1996) reported iron levels of $0.97 \mathrm{mg} / \mathrm{L}$ while Gehr and Wright (1998) noted over $3 \mathrm{mg} / \mathrm{L}$ in the final effluent.

The objectives of this study were to investigate the effect of heat and/or UV radiation on fouling of low pressure UV lamps and to assess 
the usefulness of a chemical equilibrium model $\left(\mathrm{MINEQL}^{+}\right)$to predict the fouling potential based on water quality characteristics and lamp temperature. Batch, recirculating and flow-through configurations would be explored, the first two especially to determine key chemical parameters and to assess whether recirculating systems (as used by Lin et al. 1997), with their inherent economies, could serve as alternatives to flow-through systems for such experiments. This study examined the potential for precipitation of dissolved Fe (III), derived from ferric chloride, with hydroxides or phosphates, for which Fe (III) has a strong affinity. It is assumed that the heat generated by the UV lamp is absorbed by the flowing liquid and induces inorganic salts with reverse thermal solubility (such as $\mathrm{FePO}_{4}$ ) to precipitate on the quartz sleeve. This assumption, considered from the viewpoint of solution equilibrium, is described by the van't Hoff approximation for solubility dependence on temperature.

\section{Materials and Methods}

\section{Materials}

The reactor consisted of a Plexiglas open channel with a $15.3 \mathrm{~cm} \times 30.5$ $\mathrm{cm}$ cross section and $366 \mathrm{~cm}$ long. The reactor is provided with an inlet section (77 cm deep and $31 \mathrm{~cm}$ long) and an adjustable weir at the outlet end to maintain constant water level. Low pressure mercury arc lamps (Trojan UVM 2-64 PTP, arc length $150 \mathrm{~cm}$ and input power of $87.5 \mathrm{~W}$ each) were suspended within the channel from a metal frame and oriented parallel to the flow. Two quartz windows (each of diameter $5 \mathrm{~cm}$ ), with centres aligned on the centre of the bottom lamp and between the two lamps, were inserted on one side of the Plexiglas channel. Spot measurements of the UV irradiance $(7.5 \mathrm{~cm}$ from the lamp) were made through the quartz windows using a radiometer sensor (International Light SUL 240), which was connected to a digital radiometer (International Light $\Pi$ 1400A). The sensor was provided with two filters (\# 8726 and \# 19039) for isolating UV radiation. The windows were cleaned before each measurement for the flow-through experiments only.

Aqueous solutions of iron(III) with and without phosphate ligands were used to study the effect of inorganics on fouling of the quartz sleeves. Tap water with moderate alkalinity (about $90 \mathrm{mg} / \mathrm{L}$ as $\mathrm{CaCO}_{3}$ ) served as the solvent.

Iron(III) and phosphorus were dosed as anhydrous $\mathrm{FeCl}_{3}$ and monobasic $\mathrm{KH}_{2} \mathrm{PO}_{4}$, respectively. Whey and casein powder were also added to simulate BOD and hydrophilic protein. Sample characterization showed $1 \mathrm{~g} / \mathrm{L}$ whey was equivalent to $340 \mathrm{mg} / \mathrm{L}$ BOD and $1 \mathrm{~g} / \mathrm{L}$ casein to $102 \mathrm{mg} / \mathrm{L}$ BOD. All reagents, except for the whey, were supplied by Anachemia Canada Inc. Whey powder was obtained from Fisher Scientific, Ltd.

The samples were collected as grab samples in 500-mL plastic bottles. Digestion for metals analysis (total and dissolved $\mathrm{Fe}$ ) was carried out using reagent grade nitric and hydrochloric acids using Standard Method 
3030F (APHA et al. 1995). The samples were filtered through $0.45-\mu \mathrm{m}$ membrane filters (Millipore) using a vacuum pump.

Fe was analyzed using a flame atomic spectrometer (Perkin Elmer 310). Standard solutions of $\mathrm{Fe}(0.1,0.3,0.5,1,3,5,10,20 \mathrm{mg} / \mathrm{L})$ were prepared by diluting a stock solution of Fe $(1 \mathrm{~mL}=1 \mathrm{mg} / \mathrm{L}$; Anachemia Canada Inc.). Distilled deionized water was used as dilution water.

$P$ was determined by ascorbic acid spectrometry at $885 \mathrm{~nm}$ (Spectronics $D^{+}$) using Standard Method 4500-P E (APHA et al. 1995).

The UV transmittance (at $254 \mathrm{~nm}$ ) was determined by a spectrophotometer (Beckman DU-65). The conductivity was determined using a conductivity meter (Radiometer CDM 83) equipped with a conductivity cell and temperature probe.

The effect of UV radiation on organics was characterized by measuring changes in the $\mathrm{BOD}_{5}$ and TOC. The $\mathrm{BOD}_{5}$ was determined using Standard Method 5210B (APHA et al. 1995). One capsule of Polyseed dissolved in $500 \mathrm{~mL}$ distilled water served as the seed. TOC was determined by persulfate ultraviolet oxidation (Dohrman DC-80) using Standard Method 5310S (APHA et al. 1995).

All experiments were performed at room temperature (around $22^{\circ} \mathrm{C}$ ). However, solution temperatures changed within a range of 5 to $35^{\circ} \mathrm{C}$ as a result of heat generated by the lamp and from the pump.

\section{Batch Studies}

Two sets of batch tests were conducted to yield an understanding of the reaction rates of precipitation $\left(\mathrm{Fe}(\mathrm{OH})_{3}\right.$ and $\left.\mathrm{FePO}_{4}\right)$ and the concentration of species (Fe and P) at equilibrium. It is noted that detention times in the UV reactor are typically in the order of 10 seconds (EPA 1986). Table 1 lists the operating conditions of these studies. The rates and concentrations will be compared to the laboratory experiments using the UV reactor.

Table 1. Batch studies

\begin{tabular}{llccc}
\hline & & \multicolumn{2}{c}{ Concentration (mg/L) } & \\
\cline { 3 - 4 } No. Solution & Fe & $\mathrm{P}$ & Objective \\
\hline 1 & $\mathrm{FeCl}_{3}+$ & 3 & 5 & To study the kinetics of precipitation \\
& $\mathrm{KH}_{2} \mathrm{PO}_{4}$ & 3 & 20 & \\
& & 4 & 50 & \\
2 & $\mathrm{FeCl}_{3}+$ & 20 & 50 & To investigate equilibrium \\
& $\mathrm{KH}_{2} \mathrm{PO}_{4}$ & 40 & $"$ & concentrations of soluble Fe and P \\
& 60 & $"$ & \\
& 80 & $"$ & \\
& 100 & $"$ & \\
& 120 & $"$ & \\
& 140 & $"$ & \\
\end{tabular}




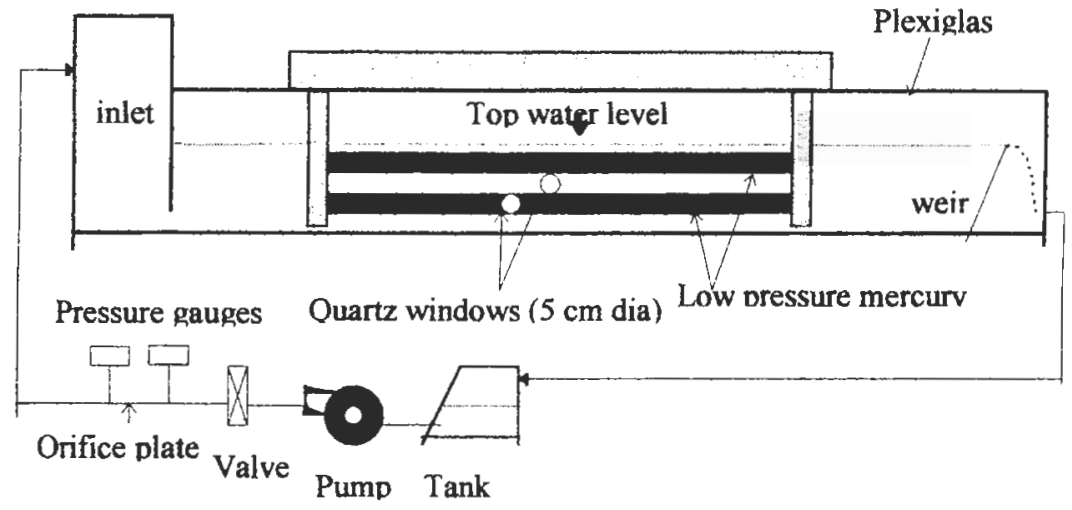

Fig. 1. Longitudinal section of UV reactor (recirculation).

\section{Recirculation Studies}

The system was operated with two low pressure mercury arc lamps oriented parallel to the flow. A longitudinal section of the reactor is shown in Fig. 1.

The iron, phosphate and/or organic solutions were prepared separately and poured into the metal tank $(235 \mathrm{~L})$. Delivery to the reactor was provided by a centrifugal pump (Jacuzzi S7DH1) via a $50 \mathrm{~cm}$ diameter PVC pipe. Flow was controlled by an in-line gate valve and measured by calibrated, in-line pressure gauges on each side of an orifice plate. The flow was initially maintained at $1.8 \mathrm{~L} / \mathrm{s}$ (i.e., $0.9 \mathrm{~L} / \mathrm{s}$ per lamp) and later reduced to $0.7 \mathrm{~L} / \mathrm{s}$. Similar hydraulic loadings have been used in previous studies (Blatchley et al.1995; Gehr and Wright, 1998; Jesien 1998). Table 2 lists the operating conditions of the study.

\section{Flow-Through Studies}

The system was operated with a single low pressure mercury lamp. Figure 2 shows a longitudinal section of the reactor.

Table 2. Recirculation studies

\begin{tabular}{lcccc}
\hline \hline & & \multicolumn{4}{c}{ Concentration $(\mathrm{mg} / \mathrm{L})$} \\
No. & Fe & $\mathrm{P}$ & $\begin{array}{c}\text { Whey } \\
(\mathrm{mg} / \mathrm{L} \text { as BOD })\end{array}$ & $\begin{array}{c}\text { Casein } \\
(\mathrm{mg} / \mathrm{L} \text { BOD })\end{array}$ \\
\hline 1 & 1 & - & - & - \\
2 & 3 & - & - & - \\
3 & 3 & 4.85 & - & - \\
4 & 3 & - & 30 & 30 \\
5 & 3 & 5.0 & - & - \\
\hline
\end{tabular}




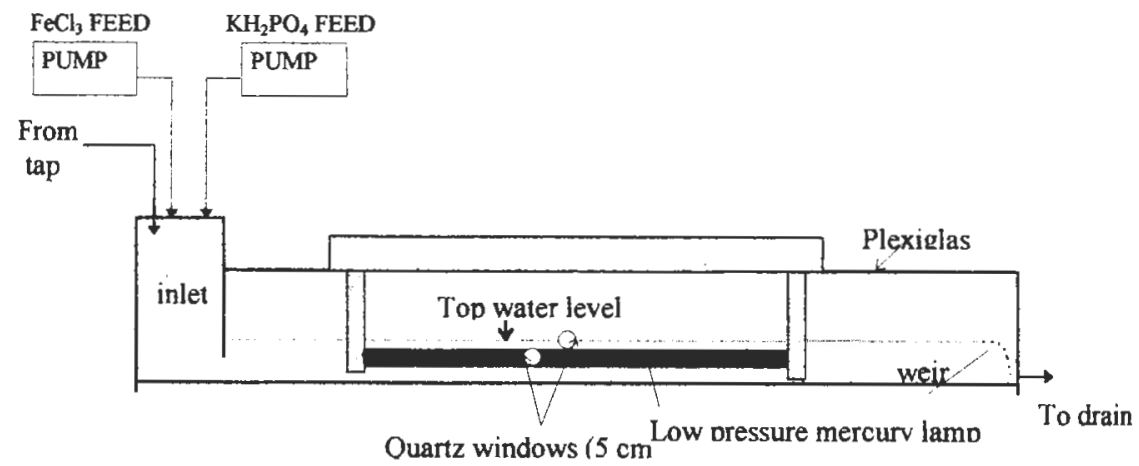

Fig. 2. Longitudinal section of UV reactor (flow-through).

Tap water was provided through a $25-\mathrm{mm}$ diameter tube into the inlet section at a rate of about $0.5 \mathrm{~L} / \mathrm{s}$. The concentrated salt solutions (of $\mathrm{FeCl}_{3}$ and/or $\mathrm{KH}_{2} \mathrm{PO}_{4}$ ) were fed into the inlet section of the channel using peristaltic pumps (PIPER D) where splash mixing occurred. The pump speeds were adjusted to provide the desired salt concentrations. Table 3 lists the operating conditions of the study.

The lamp performance in the previous two studies was investigated by monitoring fouling (through measured changes in UV irradiance) and recording changes in the solution parameters. Expected precipitation was monitored by measuring changes in dissolved species (Fe and P). Since it was not practical to vary the temperature of the lamp sleeve, the study was therefore limited to controlling the solution concentrations (Fe and P).

\section{Chemical Equilibrium Modeling with MINEQL+}

Lamp sleeve temperature measurements (in air and in solution) were made separately with an infrared camera (Minolta Cyclops Compaq) as well as with thermocouples attached to a data acquisition unit (Hewlett

Table 3. Flow-through experiments

\begin{tabular}{lcc}
\hline \hline & \multicolumn{2}{c}{ Concentration $(\mathrm{mg} / \mathrm{L})$} \\
\cline { 2 - 3 } No. & $\mathrm{Fe}$ & $\mathrm{P}$ \\
\hline 1 & 1.2 & - \\
2 & 2.7 & - \\
3 & 5.7 & - \\
4 & 10.6 & - \\
5 & 20.0 & - \\
6 & 5.0 & 5.0 \\
\hline
\end{tabular}


Packard 34970A). These measurements served as a guide for evaluating the temperature effects on solubility with the computer model.

The chemical equilibrium model, MINEQL ${ }^{+}$(Schecher and McAvoy 1994) was used to predict temperature effects on the solubilities of Fe and $\mathrm{P}$. Because the concentrations of the solutions were less than $1 \mathrm{M}$, ionic strength corrections were ignored (Pankow 1991). To study the effect of temperature on precipitation, input of the equilibrium constants ( $\log \mathrm{K}$ ) for different temperatures $\left(10\right.$ to $\left.50^{\circ} \mathrm{C}\right)$ were evaluated using the van't Hoff approximation for steady enthalpy (Benefield et al. 1982; Pankow 1991). The thermodynamic constants were obtained from Lidin et al. (1995). Table 4 lists a summary of the conditions modelled.

\section{Results and Discussion}

\section{Batch Studies}

\section{Precipitation kinetics}

Figure 3 shows the variations of soluble Fe and P with time. The results indicate that the precipitation of iron(III) can be very rapid with an almost instantaneous change of Fe and P (Fe dropping from 3 to $2 \mathrm{mg} / \mathrm{L}$ and $P$ from 5 to $4.5 \mathrm{mg} / \mathrm{L}$ ). No further significant change was observed over the following 60-minute period. For the evaluated retention times (over 40s), it is therefore conceivable that precipitation from the bulk solution within the reactor would be significant, increasing with the concentration of Fe.

\section{Equilibrium concentrations}

The stoichiometric relationships between $\mathrm{Fe}$ and $\mathrm{P}$ (i.e., assuming eventual precipitation as $\mathrm{FePO}_{4}$ ) were used in selecting initial concentra-

Table 4. Theoretical modelling with MINEQL+

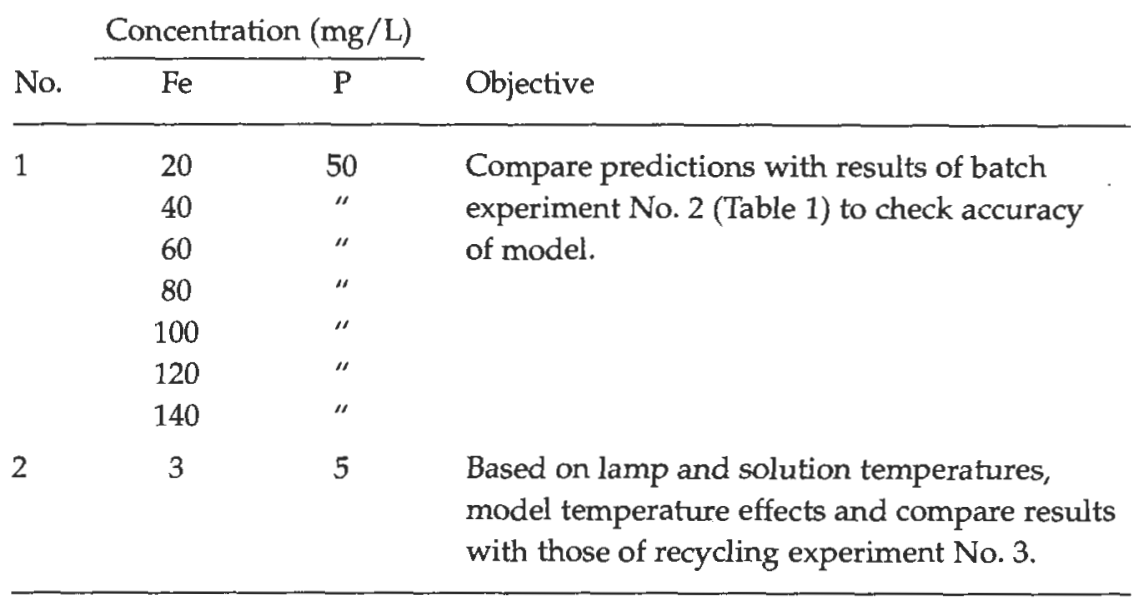




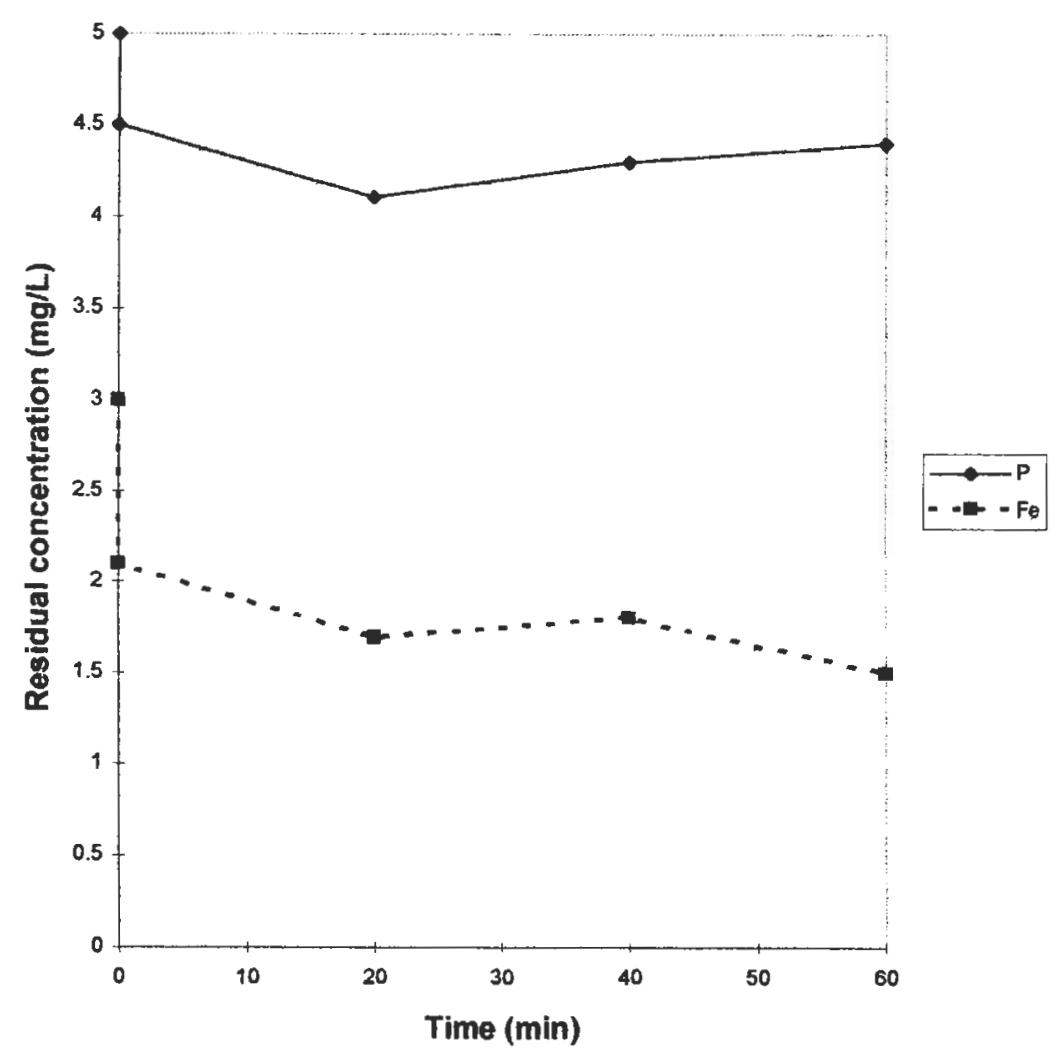

Fig. 3. Residual Fe and P: Precipitation kinetics for $3 \mathrm{mg} / \mathrm{L} \mathrm{Fe}$ and $5 \mathrm{mg} / \mathrm{L}$ $\mathrm{P}$ (batch mode).

tion ratios of chemicals to be added for the fouling tests. Increasing the concentration of iron(III) was found to affect the residual P concentration up to a mass ratio of $2 \mathrm{Fe}: 1 \mathrm{P}$. Figure 4 compares the experimental results with that of a theoretical prediction. It shows an almost linear relationship in reduction of soluble $P$ with increasing Fe dose up to a chemical weight ratio of approximately $2 \mathrm{Fe}: 1 \mathrm{P}$, beyond which an equilibrium relationship was attained. Thus $100 \mathrm{mg} / \mathrm{L}$ of Fe was required to precipitate virtually all the $50 \mathrm{mg} / \mathrm{L}$ of $\mathrm{P}$. This is slightly less than the mole ratio of 1.6 (equivalent to $3 \mathrm{Fe}: 1 \mathrm{P}$ on a mass basis) found in practice for wastewaters by Jenkins and Hermanowicz (1991).

\section{Recirculation Studies}

Temperature control of the bulk solution was initially a problem. Solution temperatures were observed to increase up to $34^{\circ} \mathrm{C}$ mainly due to heat transfer from the pump. This problem was solved by installing a radiator and cooling fan which stabilized the temperature at $15^{\circ} \mathrm{C}$.

Fe has been shown to affect UV transmittance, hence the UV irradiance (or intensity) (Mishalani et al. 1996; Soroushian et al. 1996; Gehr and Wright 


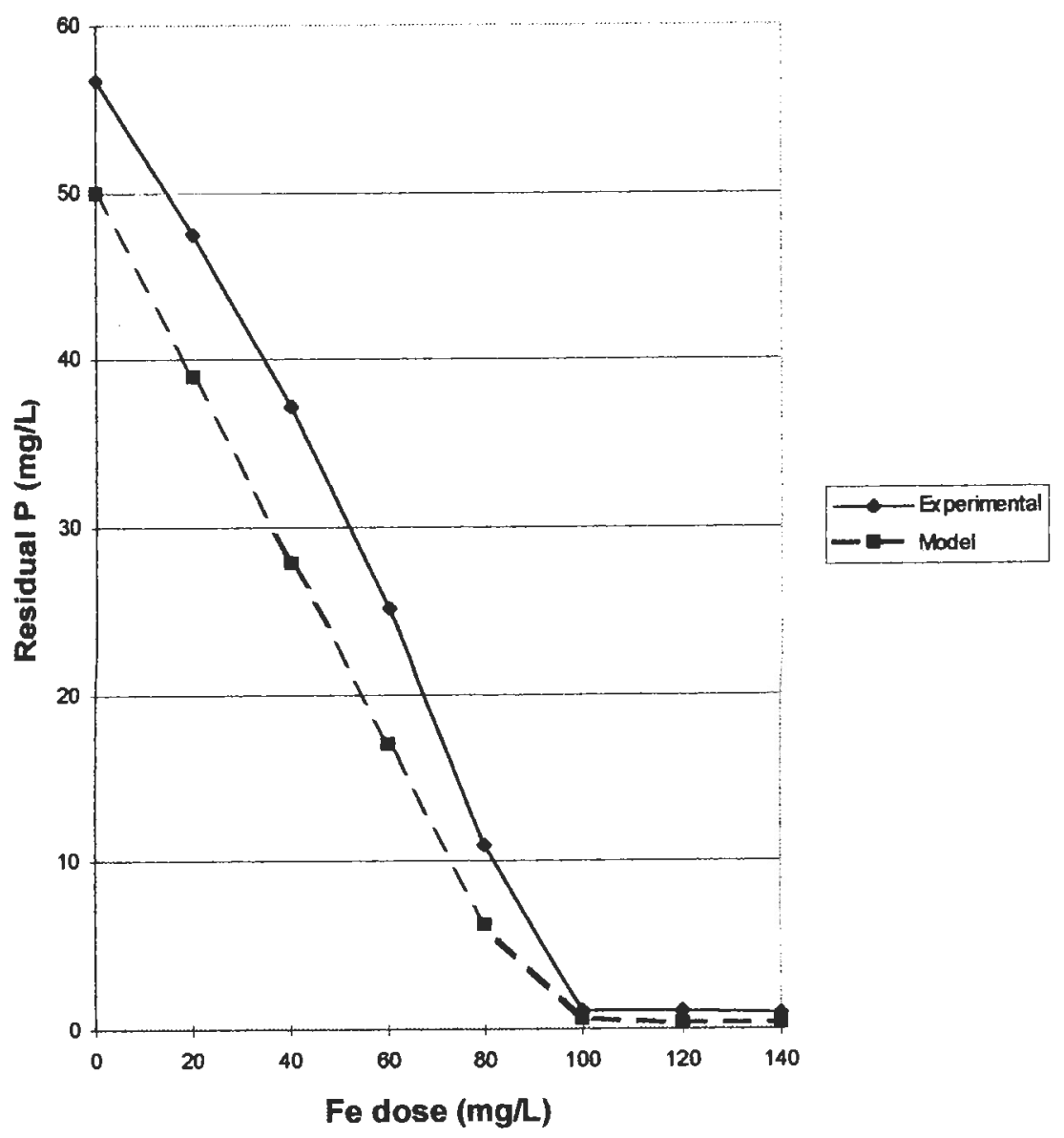

Fig. 4. Effect of Fe dose on residual $\mathrm{P}$ (experimental and $\mathrm{MINEQL}^{+}$model).

1998). UV irradiance is expected to decrease with increase in Fe levels. To compare data for different Fe doses, the measured irradiances (in $\mathrm{mW} / \mathrm{cm}^{2}$ ) were therefore normalized and reported as relative irradiances $\left(I / I_{0}\right.$, where $I_{0}$ is the initial irradiance reading and $I$ is irradiance at any subsequent time). The maximum irradiance observed was approximately $1.6 \mathrm{~mW} / \mathrm{cm}^{2}$.

\section{Fouling with inorganics (Fe alone)}

Figure 5 illustrates the variations in irradiance at an iron(III) concentration of $3 \mathrm{mg} / \mathrm{L}$. Fouling was monitored over a period of up to 12 days. The measured UV irradiances generally increased within the first two days and then appeared to fluctuate about a mean.

No coating was observed on the sleeves for the period under observation. For an iron(II) concentration of $3 \mathrm{mg} / \mathrm{L}$, the UV irradiance increased seven-fold within 3 days (Fig. 5). This was accompanied by an increase in the measured solution UV transmittance (from 53 to $96 \%$ ) for the same period. Similar results were obtained for lower iron(III) concentrations. 

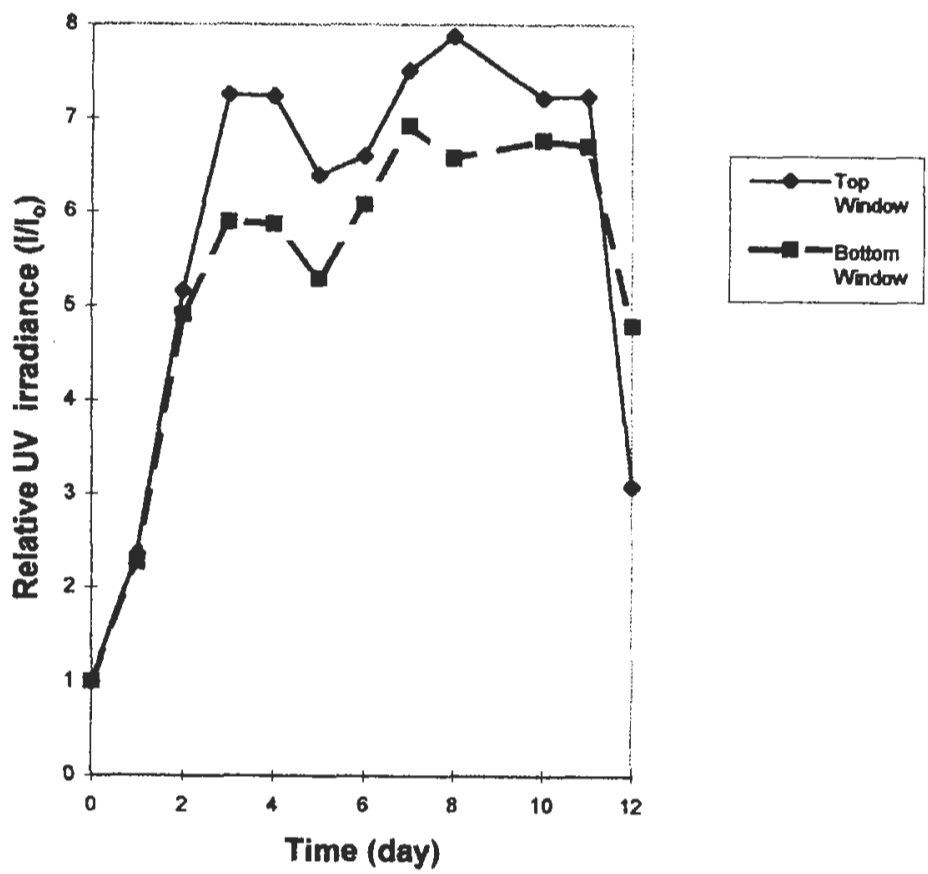

Fig. 5. Relative UV irradiance versus time for $3 \mathrm{mg} / \mathrm{L} \mathrm{Fe}$ (recirculation mode).

The initial and sharp increases in irradiance measurements can be attributed to bulk precipitation (most likely in the tank and delivery pipe), resulting in the initial increase in solution transmittance. Visual inspection of the tank did show extensive deposition of iron particles. There was no noticeable change in the measured dissolved Fe in the bulk solution during the monitoring period. This appears to support results of the batch experiments (Fig. 3) that precipitation of iron is spontaneous and almost immediate. The sharp decrease in irradiance measured on day 12 (Fig. 5) is attributed to instrumental error or possibly microbial growth in the solution (but this is unlikely, given the absence of nutrients).

\section{Fouling with inorganics (Fe and P)}

The combined addition of iron(III) and P did not appear to cause fouling of the lamps under the given test conditions. Figure 6 illustrates the variation in irradiance with recycling of a $3 \mathrm{Fe}: 5 \mathrm{P}$ solution (mass ratio).

The flow for this and subsequent experiments was reduced to $0.7 \mathrm{~L} / \mathrm{s}$ (i.e., $0.35 \mathrm{~L} / \mathrm{s}$ per lamp) in order to reduce any effect of shear or sloughing. Similar action by Jesien (1998) resulted in increased fouling of the lamp.

It was expected that $\mathrm{FePO}_{4}$, representing salts with inverse solubilities, would precipitate on the quartz surface. That this did not occur could be attributed to previous precipitation, mainly in the tank. Solution conditions such as pH may also not have favoured precipitation. Theoretical 


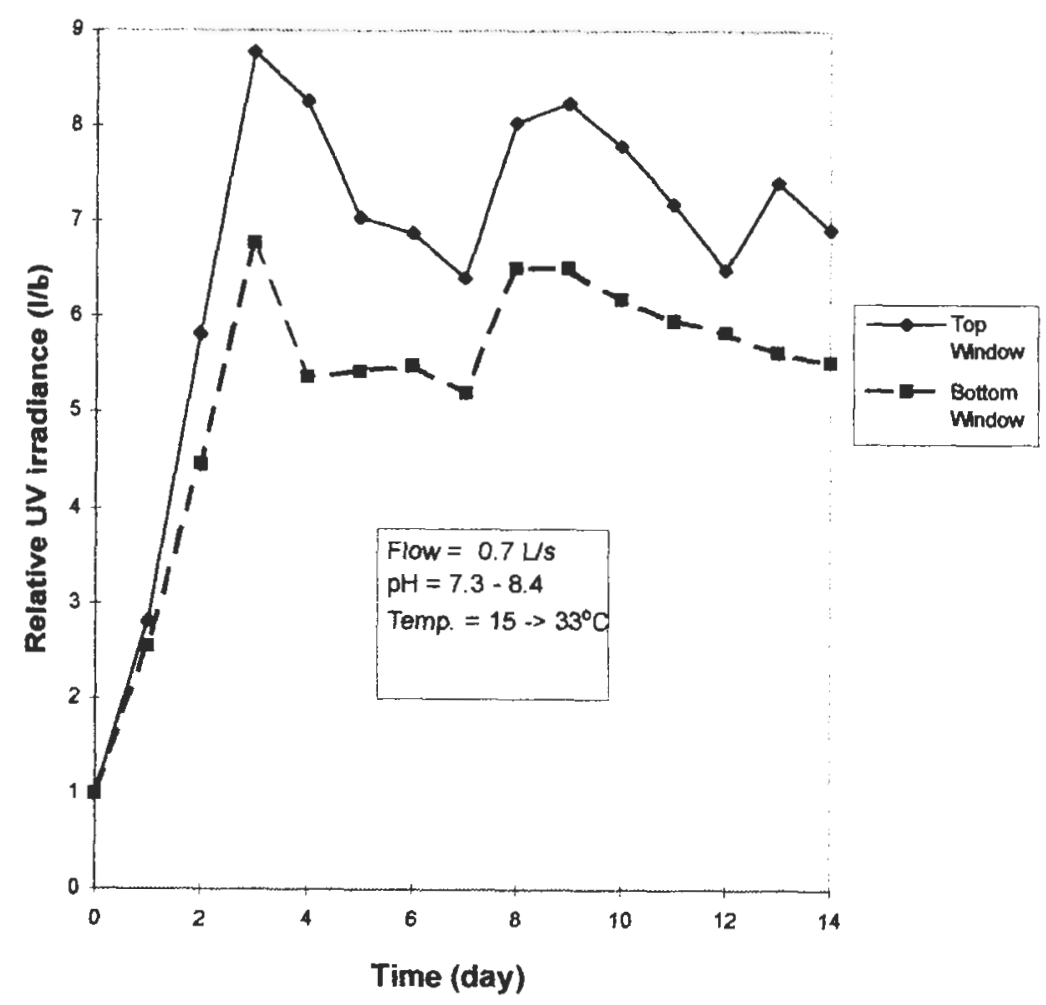

Fig. 6. Relative UV irradiance versus time for $3 \mathrm{mg} / \mathrm{L} \mathrm{Fe}$ and $4.85 \mathrm{mg} / \mathrm{L} \mathrm{P}$ (recirculation mode).

predictions with the MINEQL ${ }^{+}$model suggest little or no impact of temperature change $\left(30\right.$ to $50^{\circ} \mathrm{C}$ ) on $\mathrm{FePO}_{4}$ precipitation at a $\mathrm{pH}$ greater than 7. The irradiance increased nine-fold within 2 days, then appeared to fluctuate about a mean (Fig. 6).

\section{Fouling with organics}

The experiment was extended to study the effect of UV radiation using iron(III) in the presence of organic compounds. Two such compounds were used: whey and casein, at a dose of $30 \mathrm{mg} / \mathrm{L}$ as BOD to reflect typical wastewater effluent concentrations. The solutions were prepared in a mass ratio of 3Fe:30BOD and 3Fe:5P:30 BOD for whey and casein, respectively. Figure 7 illustrates the variation in UV irradiance over time for the whey solution. Results (not shown) for the casein solution yielded a similar pattern. There was still no evidence of fouling.

An interesting observation for all the recirculation experiments was the sharp increase in solution transmittance (up to $90 \%$ within 4 days). Bulk precipitation was observed as exhibited by orange-brown particle deposition at the bottom of the tank and channel. The influence of heat and/or irradiation from the lamps was therefore not evident. 


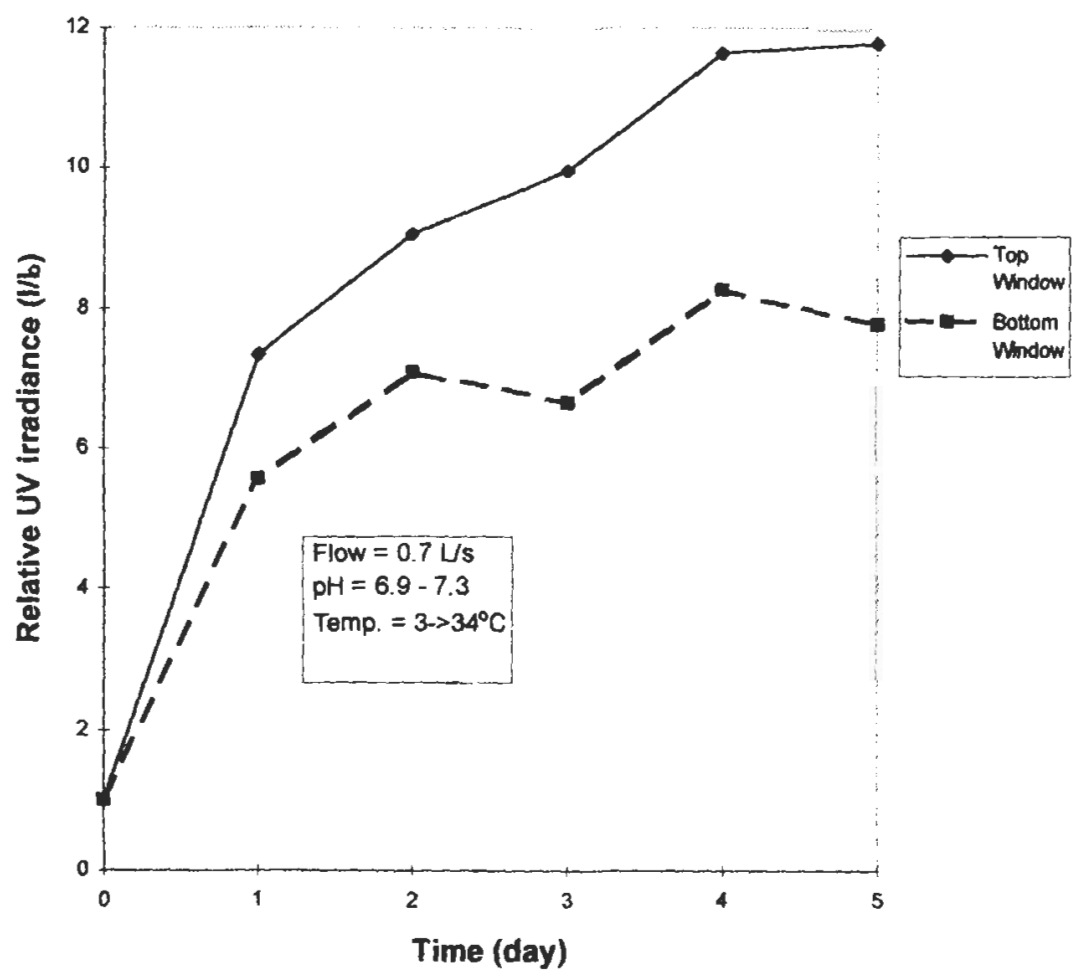

Fig. 7. Relative UV irradiance versus time for $3 \mathrm{mg} / \mathrm{L} \mathrm{Fe}$ and $30 \mathrm{mg} / \mathrm{L} \mathrm{BOD}$ (as whey) (recirculation mode).

\section{Effect on organics}

Although not directly related to this study, changes in the $\mathrm{BOD}_{5}$ and TOC levels for the addition of $\mathrm{Fe}, \mathrm{P}$ and casein (Experiment No. 5, recirculation studies) were measured. The results show decreasing BOD and TOC levels over time (Fig. 8). It is expected that $U V$ radiation will have an impact on organic compounds. However, for the given test conditions, the exact relationship of UV irradiance and BOD/TOC removal cannot be established from these results, and it is also possible that the removal of proteins could have occurred by their entrapment in the precipitating iron/phosphate complexes.

$B O D_{5}$ removal and TOC removal over an 8-day period were estimated as $30 \%$ and $50 \%$, respectively.

\section{Flow-Through Studies}

\section{Fouling with inorganics (Fe alone)}

Iron(III) concentrations ranging from 1 to $20 \mathrm{mg} / \mathrm{L}$ (as described in Table 3) were fed through the reactor. Variations in the UV irradiance were 


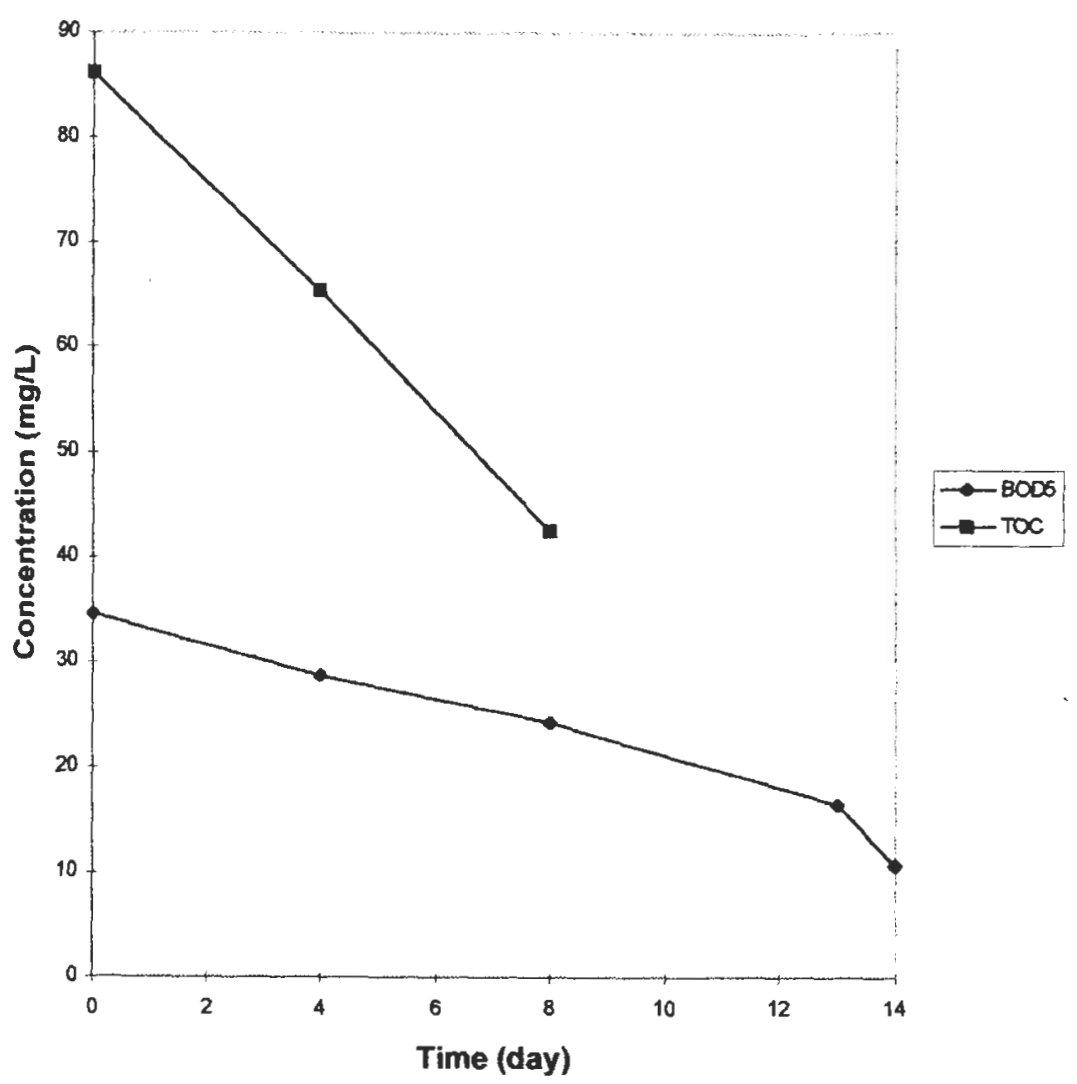

Fig. 8. Effect on organics $\left(\mathrm{BOD}_{5}\right.$ and TOC removal.

plotted against elapsed time for iron (III) concentrations of 1.2, 2.7, 5.7 and $10.6 \mathrm{mg} / \mathrm{L}$ (Fig. 9). In contrast to the previous experiments, a marked and consistent decrease in UV irradiance was observed. For an Fe level of $1.2 \mathrm{mg} / \mathrm{L}$, a $50 \%$ reduction in UV irradiance was observed after almost 3 days, whereas Fe levels over $2.7 \mathrm{mg} / \mathrm{L}$ showed a similar reduction in less than a day. Also, the quartz windows were observed to foul during the continuous flow-through experiments. Therefore, the windows were wiped with a cotton swab soaked in nitric acid prior to taking each reading.

The results show that the rate of decrease in UV irradiance (measured at the quartz window) was initially steady and rapid but diminished over time. This would indicate that the accumulation of deposits was followed by a removal process.

Thus, solids deposition and removal rate stabilized in less than a day for Fe greater than $3 \mathrm{mg} / \mathrm{L}$, and in 3 days for lower Fe concentrations. Furthermore, the absence of a lengthy initiation period in these figures would suggest the spontaneous precipitation and/or deposition on the lamp surface. 


\section{Fouling with inorganics (Fe and $\mathrm{P}$ )}

Figure 9 also illustrates the variation of irradiance with a dosing of $\mathrm{Fe}$ and $\mathrm{P}$ in a mass ratio of 5:5. As with $\mathrm{Fe}$ (III) alone, fouling is characterized by a steady but rapid decrease in irradiance and the absence of a lengthy initiation period. This condition is most noticeable with the addition of $P$. Figure 9 shows an $80 \%$ reduction in irradiance within 5 hours for an Fe:P ratio of 5:5. On the other hand, a similar reduction in irradiance using $\mathrm{Fe}$ alone at $10.6 \mathrm{mg} / \mathrm{L}$ took one day, and lower Fe concentrations had an even slower effect on changes in UV irradiance. Therefore, dosing Fe with $P$ substantially increased the rate of fouling compared to that without $P$.

The length of time for the irradiance to decrease by $50 \%$ ( $\mathrm{I}_{50}$ ) as a function of Fe dose is shown in Fig. 10. In general, values for $\mathrm{I}_{50}$ decreased

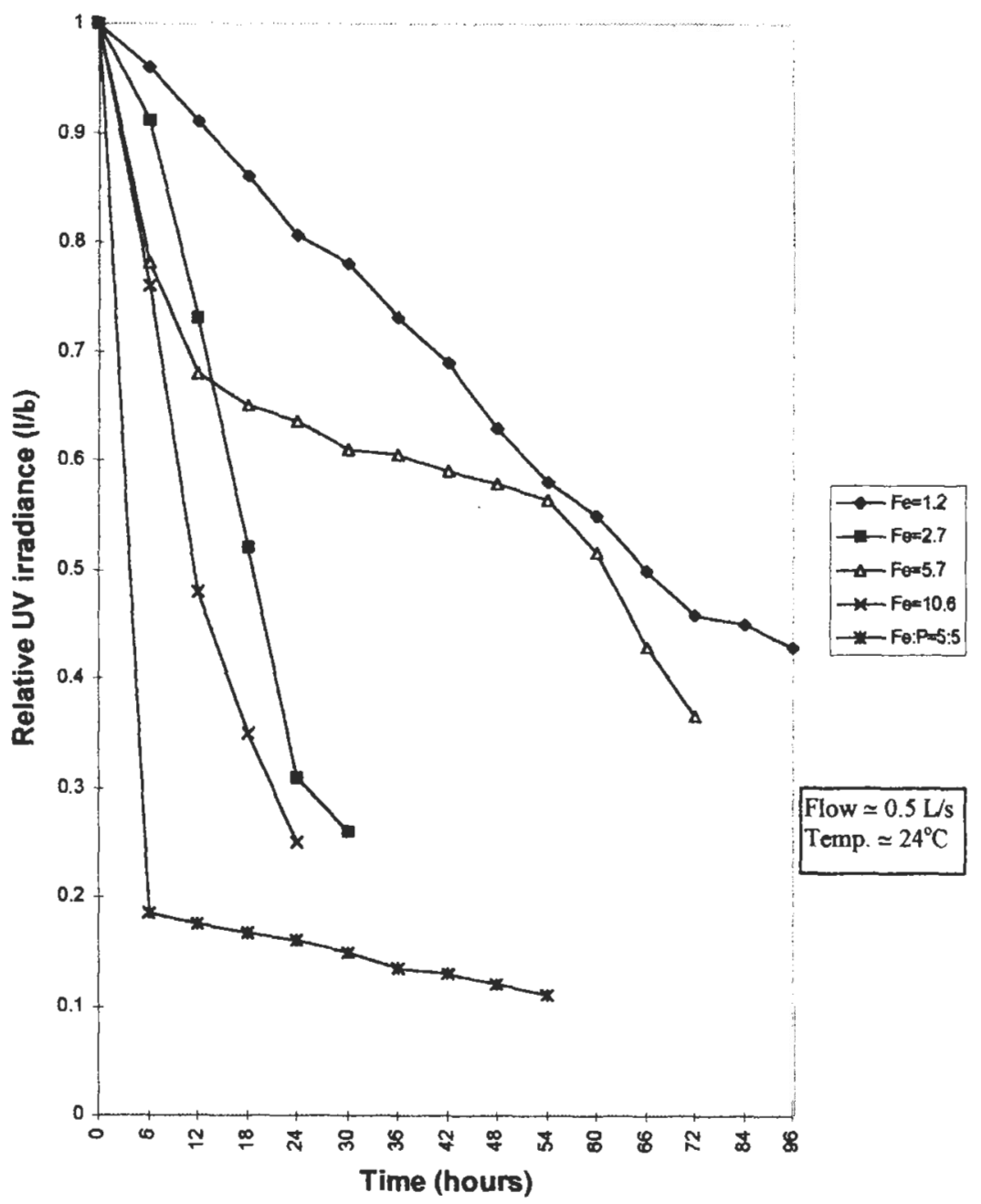

Fig. 9. Relative UV irradiance versus time for different Fe concentrations (flow-through mode). 


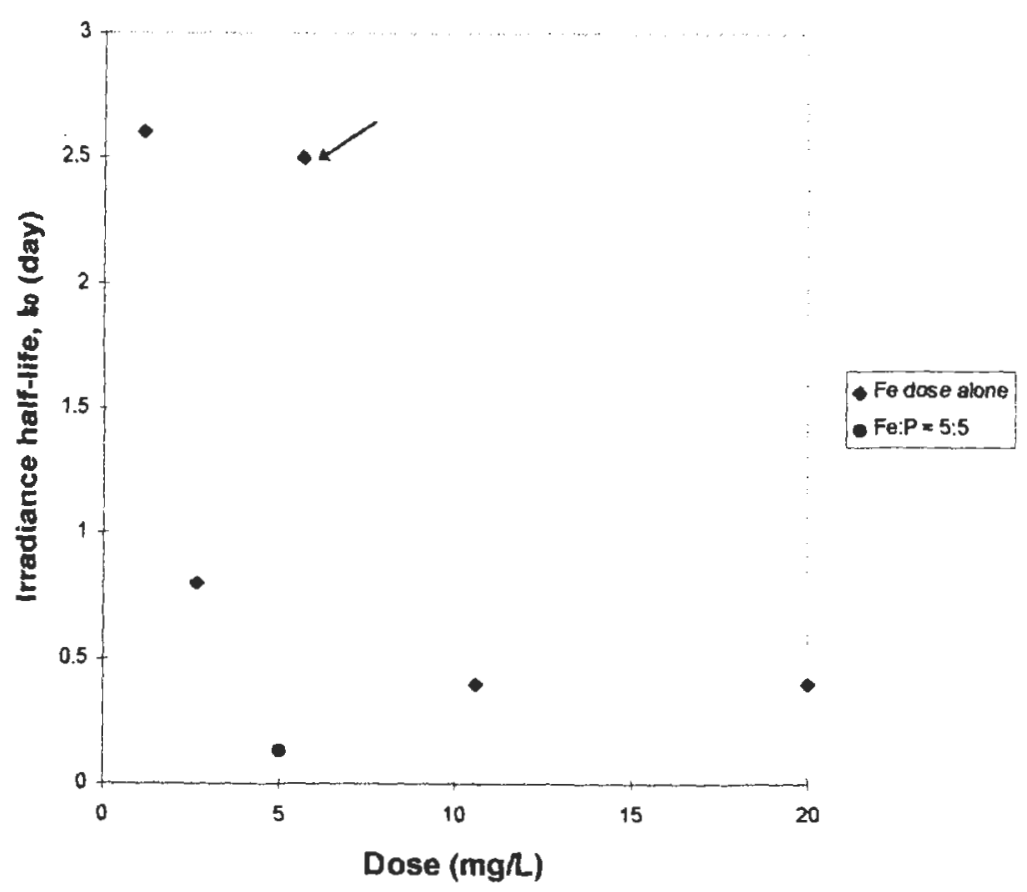

Fig. 10. UV irradiance half-life as a function of Fe dose.

with increase in $\mathrm{Fe}$ (III) dose. However, the result for an $\mathrm{Fe}$ (III) dose of 5 $\mathrm{mg} / \mathrm{L}$ (arrowed in the figure) was inconsistent and showed an unexpectedly slow rate in decrease of the UV irradiance. Increasing the iron concentration above $10 \mathrm{mg} / \mathrm{L}$ did not appear to produce a marked change in the decrease of UV irradiance.

Because a homogenous solution was used, no attempt was made to characterize the fouling material. Also, the accumulated material was not quantified. However, at the end of each experiment, the lamps were inspected to observe the distribution of material on the quartz surface. The material appeared to be of loose structure varying from yellowishbrown to brown in colour. This is consistent with the appearance of $\mathrm{Fe}(\mathrm{OH})_{3}, \mathrm{FePO}_{4}$, and combinations of $\mathrm{Fe}, \mathrm{Ca}$, and $\mathrm{Mg}$ precipitates. Material accumulation was greatest on the top of the lamp with the sides showing the least accumulation. Considering the low velocities and the rapid precipitation of iron (Fig. 3), solids accumulation on the quartz surface can be attributed mostly to sedimentation of the iron particles. Although thermal-induced precipitation cannot be ruled out, and preformed particles may also attach randomly to sleeve surfaces, these results show that they would not be dominant mechanisms. Furthermore, measurements of the lamp temperature distribution did not show marked changes either radially $\left(43.7\right.$ to $\left.49.9^{\circ} \mathrm{C}\right)$ or longitudinally $\left(44.7\right.$ to $\left.49.3^{\circ} \mathrm{C}\right)$. Finally, the growth of colloidal deposits on the sleeves by nucleation is unlikely to occur during the short time period of the experiments 
(Pankow 1991). Therefore, particle sedimentation is likely to be the initial and dominant mechanism.

\section{Theoretical Modelling of Temperature Effects (MINEQL+)}

Changes in precipitation can be monitored by measuring the soluble species, which serve as an indicator of the precipitation potential of a salt. A computer model, $\mathrm{MINEQL}^{+}$, was used to predict the effect of lamp sleeve temperature on ligand concentration. The precipitation potentials of two salts $\left(\mathrm{Fe}(\mathrm{OH})_{3}\right.$ and $\left.\mathrm{FePO}_{4}\right)$ were simulated using concentrations described in Table 4 . The reactions and calculated equilibrium constants used as input for the model are shown in Table 5. Polynuclear species of Fe such as hematite $\left(\mathrm{Fe}_{2} \mathrm{O}_{3}\right)$ were neglected in the reaction. Also, other solid forms of $\mathrm{Fe}$ (III) such as goethite $(\mathrm{FeOOH})$ were not considered. Pankow (1991) notes that while Fe(III) initially precipitates as amorphous $\mathrm{Fe}(\mathrm{OH})_{3}$, conversion of the latter to forms such as goethite and hematite could take weeks, and this is not applicable to the time frame considered in these experiments.

As a first check on the accuracy of the computer model, predictions of the residual $\mathrm{P}$ with increasing $\mathrm{Fe}$ dose, as described in Table 1, were compared with results of the batch experiments (Fig. 4). The results show similar trends. It is noted that the $\mathrm{pH}$ values in the batch tests were observed to fluctuate between 7 and 3 (uncontrolled) whereas the model predictions were made for a constant $\mathrm{pH}$ value of 7 . This, as well as the fact that the model assumed instantaneous kinetics, may explain the relatively large deviations at lower Fe doses.

Because it was not appropriate to measure changes in the bulk Fe (or $P$ ) levels in the flow-through experiments (since these were designed to be constant), model predictions of temperature effects could only be compared with results of the recirculation experiments. Model predictions for temperature effects were therefore compared to actual measured concentrations in Experiment No. 3 of the recirculation tests as described in Table 2 (i.e., for 3Fe:4.85P). Figure 11 shows the model predictions for variations in bulk Fe and $\mathrm{P}$ concentrations due to temperature effects at a $\mathrm{pH}$ of 7 . This was the approximate $\mathrm{pH}$ in the recirculation test.

The results show that, for temperatures ranging from 10 to $50^{\circ} \mathrm{C}$, the expected changes in bulk Fe and $\mathrm{P}$ are $0.98 \mathrm{mg} / \mathrm{L}$ and $0.54 \mathrm{mg} / \mathrm{L}$, representing a decrease of $45 \%$ and $12 \%$, respectively. These changes are far lower than those actually measured (Fig. 12), which show a decrease in dissolved iron from $2.3 \mathrm{mg} / \mathrm{L}$ to approximately $0.2 \mathrm{mg} / \mathrm{L}$ while soluble phosphorus decreased from $2.34 \mathrm{mg} / \mathrm{L}$ to approximately $1.2 \mathrm{mg} / \mathrm{L}$. These represent decreases of $91 \%$ and $49 \%$ for Fe and $\mathrm{P}$, respectively. It is recognized that agreement between model predictions and experimental results may not be exact. Substantial precipitation of the bulk solution was observed at the bottom of the channel and tank. Also, Pankow (1991) notes that discrepancies could arise from a) the assumption of the system to be in equilibrium, i.e., failing to account for reaction kinetics; $b$ ) failing to consider activity corrections; c) failing to accurately define the chemi- 
Table 5. Temperature dependence of $\mathrm{Log} \mathrm{K}$ for $\mathrm{FePO}-\mathrm{Fe}(\mathrm{OH})_{3}-\mathrm{H}_{2} \mathrm{O}$ system

\begin{tabular}{|c|c|c|c|c|c|c|c|}
\hline \multirow[b]{2}{*}{ Reaction (species) } & \multirow{2}{*}{$\begin{array}{c}\Delta \mathrm{H}_{\mathrm{f}}^{\circ} \\
(\mathrm{kCal} / \mathrm{mol})\end{array}$} & \multicolumn{6}{|c|}{ Log $\mathrm{K}$ at temperature $\left({ }^{\circ} \mathrm{C}\right)$} \\
\hline & & 10 & 20 & 25 & 30 & 40 & 50 \\
\hline $\mathrm{Fe}^{3+}$ & 0 & 0 & - & - & - & - & - \\
\hline $\mathrm{Fe}^{3+}+\mathrm{H}_{2} \mathrm{O}-\mathrm{H}^{+}=\mathrm{FeOH}^{2+}$ & 10.516 & -2.51 & -2.23 & -2.10 & -1.98 & -1.73 & -1.51 \\
\hline $\mathrm{Fe}^{3+}+2 \mathrm{H}_{2} \mathrm{O}-2 \mathrm{H}^{+}=\mathrm{Fe}(\mathrm{OH})_{2}^{+}$ & 10.401 & -7.06 & -6.79 & -6.66 & -6.53 & -6.29 & -6.07 \\
\hline $\mathrm{Fe}^{3+}+3 \mathrm{H}_{2} \mathrm{O}-3 \mathrm{H}^{+}=\mathrm{Fe}(\mathrm{OH})_{3}{ }^{\circ}$ & 9.856 & -9.50 & -9.24 & -9.11 & -8.99 & -8.77 & -8.55 \\
\hline $\mathrm{Fe}^{3+}+4 \mathrm{H}_{2} \mathrm{O}-4 \mathrm{H}^{+-}=\mathrm{Fe}(\mathrm{OH})_{4}^{-}$ & 9.212 & -21.74 & -21.50 & -21.38 & -21.27 & -21.06 & -20.86 \\
\hline $\mathrm{PO}_{4}^{3-}$ & 0 & & & & & & \\
\hline $\mathrm{H}^{+}+\mathrm{PO}_{4}^{3-}=\mathrm{HPO}_{4}^{2-}$ & -3.585 & 12.41 & 12.31 & 12.27 & 12.23 & 12.14 & 12.07 \\
\hline $2 \mathrm{H}^{+}+\mathrm{PO}_{4}^{2-}=\mathrm{H}_{2} \mathrm{PO}_{4}^{-}$ & -4.541 & 19.63 & 19.51 & 19.45 & 19.40 & 19.30 & 19.20 \\
\hline $3 \mathrm{H}^{+}+\mathrm{PO}_{4}^{-}=\mathrm{H}_{3} \mathrm{PO}_{4}$ & -2.629 & 21.84 & 21.77 & 21.73 & 21.70 & 21.64 & 21.58 \\
\hline $\mathrm{Fe}^{3+}+\mathrm{H}^{+}+\mathrm{PO}_{4}^{3-}=\mathrm{FeHPO}_{4}^{+}$ & -7.409 & 23.60 & 23.40 & 23.31 & 23.22 & 23.05 & 22.89 \\
\hline $\mathrm{Fe}^{3+}+3 \mathrm{H}_{2} \mathrm{O}-3 \mathrm{H}^{+}=\mathrm{Fe}(\mathrm{OH})_{3(\mathrm{~s})}$ & 20.556 & -6.47 & -5.93 & -5.67 & -5.42 & -4.95 & -4.51 \\
\hline $\mathrm{Fe}^{3+}+\mathrm{PO}_{4}^{3-}=\mathrm{FePO}_{4}(\mathrm{~s})$ & 7.409 & 25.65 & 25.85 & 25.94 & 26.03 & 26.20 & 26.36 \\
\hline $\mathrm{H}_{2} \mathrm{O}-\mathrm{H}^{+}=\mathrm{OH}^{-}$ & 13.384 & -14.54 & -14.19 & -14.02 & -13.86 & -13.55 & -13.26 \\
\hline
\end{tabular}


cal system components and to account for all possible chemical reactions and d) uncertainty of the equilibrium constants, K. Only the last two factors are thought to significantly affect these results as explained below.

The presence of other metals (such as $\mathrm{Ca}$ at $35 \mathrm{mg} / \mathrm{L}$ and $\mathrm{Mg}$ at 9.2 $\mathrm{mg} / \mathrm{L}$ contained in the tap water) were ignored in the model reactions. The only solids considered in the model reactions were $\mathrm{FePO}_{4}$ and $\mathrm{Fe}(\mathrm{OH})_{3}$. Other forms of solid phosphates and hydroxides of $\mathrm{Fe}(\mathrm{III})$ such as strengite $\left(\mathrm{FePO}_{4}-2\left(\mathrm{H}_{2} \mathrm{O}\right)\right)$ and goethite $(\mathrm{FeOOH})$ were also not considered. Finally, dependence of the equilibrium constants (obtained from Lidin et al. 1995) on temperature were determined assuming a constant enthalpy change. This may not necessarily be the case. The foregoing indi-

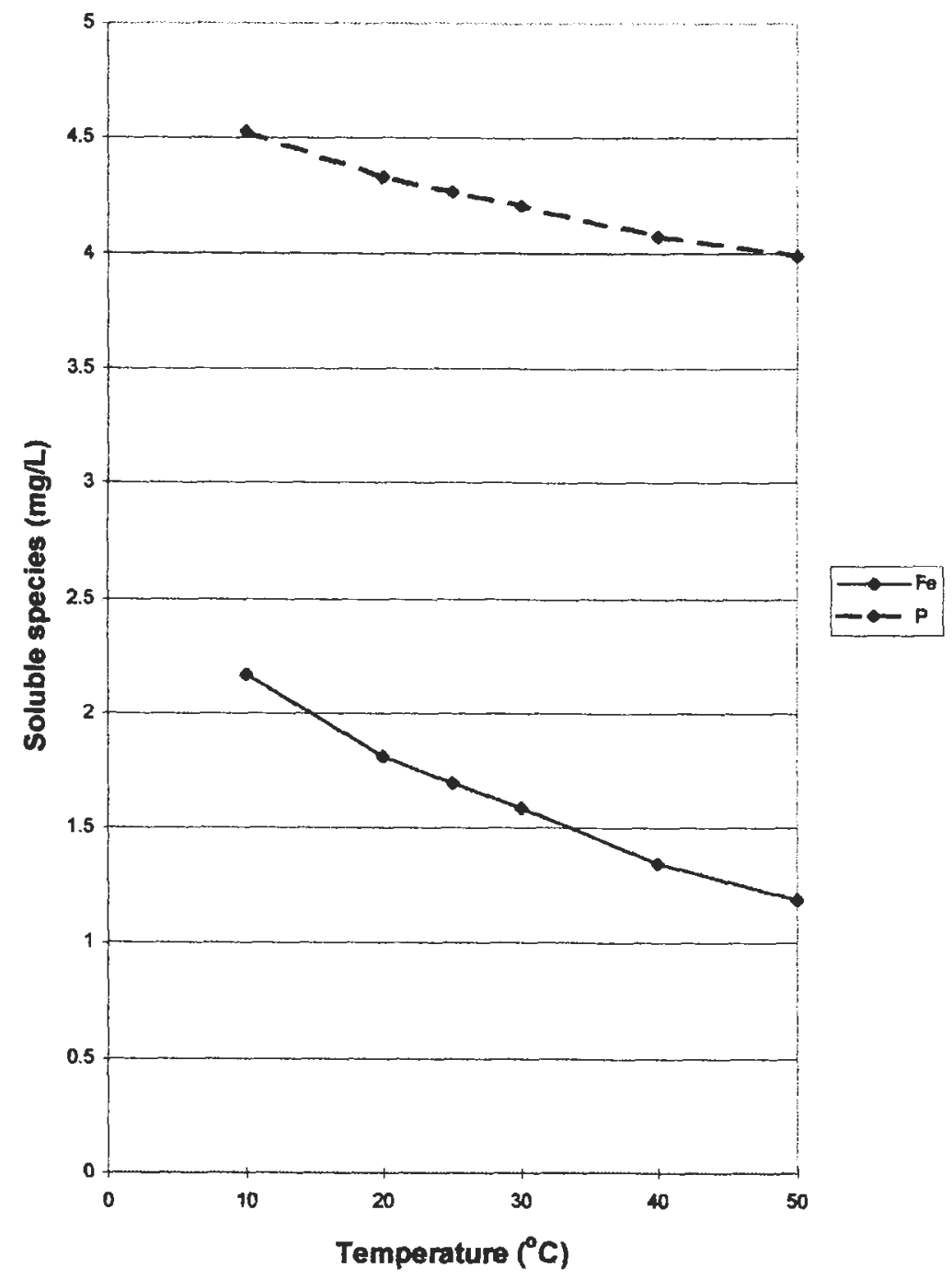

Fig. 11. Effect of temperature on soluble Fe and $\mathrm{P}$ for $\mathrm{FePO}_{4}-\mathrm{Fe}(\mathrm{OH})_{3}-\mathrm{H}_{2} \mathrm{O}$ system at $\mathrm{pH}$ of 7 for initial $\mathrm{Fe}=3 \mathrm{mg} / \mathrm{L}$ and $\mathrm{P}=5 \mathrm{mg} / \mathrm{L}\left(\mathrm{MINEQL}^{+}\right)$. 
cate that heat considerations alone could not account for precipitation fouling of the UV lamp sleeves.

Results obtained from the MINEQL ${ }^{+}$model could also be used to give an indication of mass balances. The expected concentrations of $\mathrm{Fe}$ and $\mathrm{P}$, for the flow-through experiments, in solution and precipitated, are given in Table 6. Experimental verification of the mass balance showing the distribution of reactants ( $\mathrm{Fe}$ and $\mathrm{P}$ ) on the lamp sleeve, reactor walls and base, and in solution would require sampling in all these regions this was beyond the scope of the present work.

Despite the above shortcomings, the $\mathrm{MINEQL}^{+}$model could serve as a useful tool to indicate the precipitation potential of a given chemical sys-

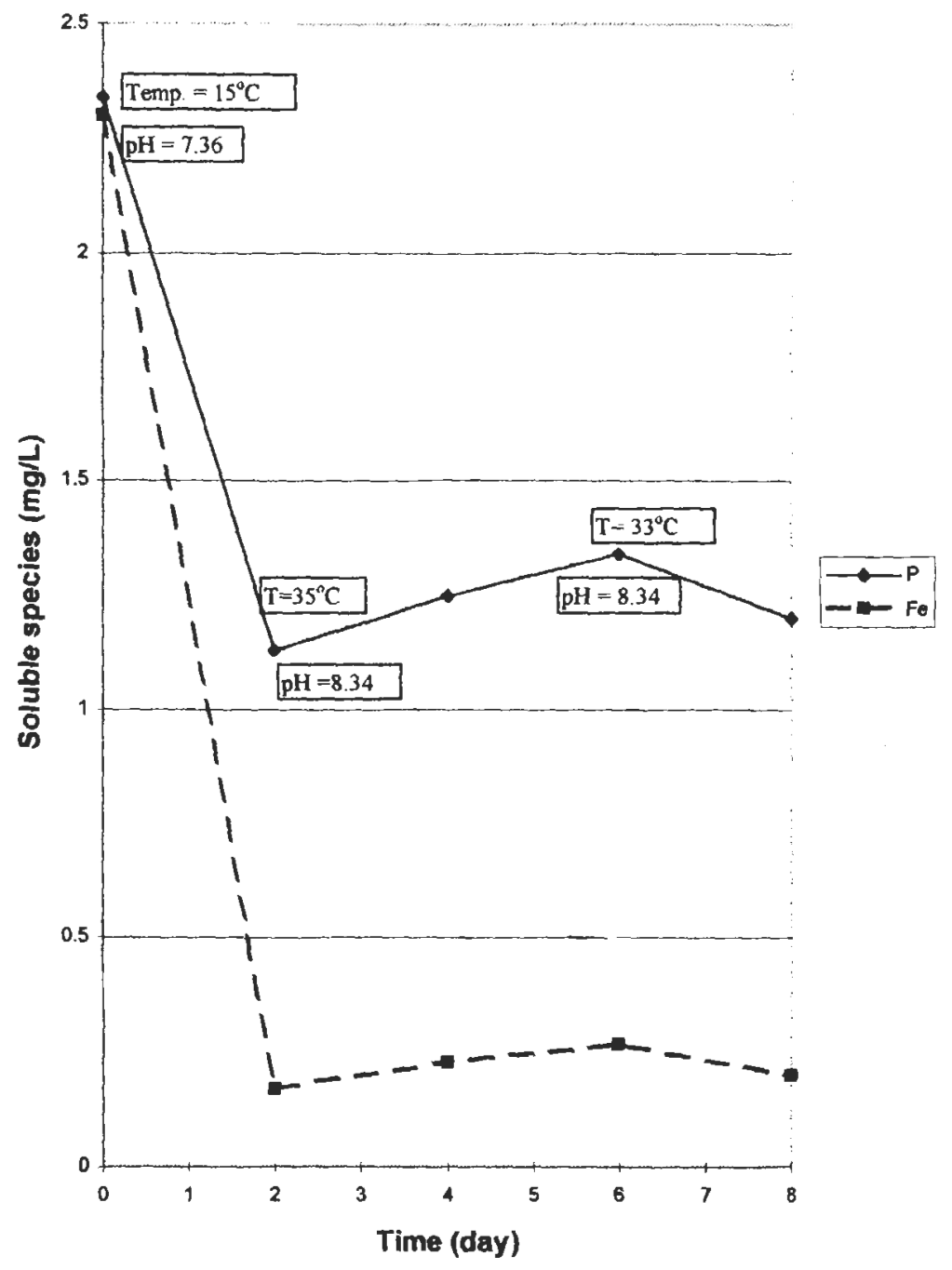

Fig. 12. Variation in soluble $\mathrm{Fe}$ and $\mathrm{P}$ during recycling experiment $(\mathrm{Fe}=$ $3 \mathrm{mg} / \mathrm{L}$ and $\mathrm{P}=4.85 \mathrm{mg} / \mathrm{L}$. (Note: values on chart denote solution conditions while air temperature varied between 22 and $25^{\circ} \mathrm{C}$.) 
Table 6. Mass balances obtained from MINEQL ${ }^{+a}$

\begin{tabular}{cccc}
$\begin{array}{c}\text { Total concentration } \\
\text { added } \\
\text { Fe:P }\end{array}$ & $\begin{array}{c}\text { Dissolved concentration } \\
\text { (from MINEQL+) } \\
\text { Fe:P }\end{array}$ & $\begin{array}{c}\text { Fe precipitated } \\
\text { (calculated) }\end{array}$ & $\begin{array}{c}\text { P precipitated } \\
\text { (calculated) }\end{array}$ \\
\hline (mg/L:mg/L) & $(\mathrm{g} / \mathrm{d})$ & $(\mathrm{g} / \mathrm{d})$ \\
\hline $1.2: 0$ & $1.2: 0$ & 0 & - \\
$2.7: 0$ & $1.2: 0$ & 64.8 & - \\
$5.7: 0$ & $1.3: 0$ & 190 & - \\
$5: 5$ & $1.3: 3.8$ & 159.8 & 51.8 \\
\hline
\end{tabular}

a Flow is assumed constant at $0.5 \mathrm{~L} / \mathrm{s}$ and solution $\mathrm{pH}$ is 7 .

tem. This would require accurate determination of all the chemical components as well as the solution conditions such as $\mathrm{pH}$ and temperature. However, the usefulness of the model is limited by its inability to account for transport mechanisms. Although this requires further studies, it would not be unreasonable to expect that heat from the lamp could contribute to the metal precipitation.

\section{Conclusions}

The results of this study indicate the importance of bulk precipitation, especially at high Fe concentrations. For iron(III) concentrations above $3 \mathrm{mg} / \mathrm{L}$, precipitation was observed to be rapid and almost immediate. Therefore, it would be unlikely to find soluble Fe levels much above this in full-scale systems. In the recirculation experiments, the formed precipitates were observed to settle largely on to the tank bottom and, to a lesser extent, on to the delivery pipe walls. The decrease in the bulk Fe (dissolved) resulted in increased solution UV transmittance. Fouling was not observed over an extended period of up to 12 days. Thus a recirculation flow regime would be inappropriate for fouling studies. On the other hand, in the flow-through experiments, the formed precipitates were associated with a decrease in UV irradiance $(50 \%$ reduction within a day, for Fe over $2.7 \mathrm{mg} / \mathrm{L}$ ) signaling the incidence of fouling. Given the low flow (approximately $0.5 \mathrm{~L} / \mathrm{s}$ ), it is proposed that sedimentation of the precipitate on to the lamp surface was the dominant mechanism which initiated fouling. The fouling material was distributed mainly on the top of the lamp surface; fouling on the bottom surface was thin while the sides showed the least accumulation of material.

The rate and extent of fouling was dependent not only on solution concentration but also on the type of ligands. While the irradiance decreased by $80 \%$ in one day using only Fe $(10.6 \mathrm{mg} / \mathrm{L})$, a similar decrease was obtained in 5 hours when $\mathrm{Fe}$ and $\mathrm{P}$ were dosed in a mass ratio of 5:5. 
Results from the computer model (MINEQL ${ }^{+}$) indicate that temperature could substantially affect the precipitation of Fe(III). Model predictions suggest that a temperature increase from 10 to $50^{\circ} \mathrm{C}$ (range taken from temperature measurements of lamp sleeve surface) could result in a decrease in soluble concentrations of $45 \%$ for Fe and $12 \%$ for $P$. These percentages were far lower than the measured decreases $(91 \%$ and $49 \%$ for $\mathrm{Fe}$ and $\mathrm{P}$, respectively, at around $34^{\circ} \mathrm{C}$ ). The differences could be attributed to the fact that the model study did not account for $\mathrm{pH}$ changes or time effects. However, if the chemical system were to be more accurately defined, the model could serve as a useful tool for predicting the precipitation potential of an effluent.

The above results do not support the hypothesis of heat-induced precipitation of salts with reverse solubility. Since particle sedimentation appears to be the dominant mechanism, this suggests that in order to reduce precipitation fouling, adequate flows need to be maintained and/or the UV system should be designed to maximize shear effects.

\section{Acknowledgments}

This study was supported by the Environmental Science and Technology Alliance Canada (ESTAC) and Trojan Technologies Inc. A grant from the Canadian Commonwealth Scholarship Program (CCSP) for M. Sheriff is gratefully acknowledged.

\section{References}

Aarts JBA. 1997. The growing importance of UV disinfection. Water Irrig. Rev. 17 (2):22-27.

APHA-AWWA-WEF. 1995. Standard methods for the examination of waters and wastewaters, 19th ed. American Public Health Association, Washington, DC.

Benefield LD, Judkins JF, Weand BL. 1982. Process chemistry for water and wastewater treatment. Prentice-Hall, NJ.

Blatchley III E, Wood WL, Schuerch P. 1995. UV pilot testing: irradiance distribution and hydrodynamics. J. Environ. Eng. Div. ASCE. 121 (3):258-262.

Blatchley III ER, Bastian KC, Duggirala RK, Alleman JA, Moore M, Schuerch P. 1996. Ultraviolet irradiation and chlorination/dechlorination for municipal wastewater disinfection: assessment of performance limitations. Water Environ. Res, 68 (2):194-204.

Cairns W. 1996. Comparison of UV disinfection technologies using low irradiance monochromatic and high irradiance polychromatic UV lamps, p. 10-47:10-52. Proceedings, Disinfecting Wastewater for Discharge \& Reuse. WEF, Portland, OR.

Diamant BZ. 1996. Water treatment: the ultraviolet option. Water Irrig. Rev. 16 (3):24-30.

EPA. 1986. Design manual: municipal wastewater disinfection. Washington, DC.

Gehr R, Comair CB, Cairns WL. 1993. UV disinfection of wastewater by medium pressure lamps, p. 1929-1936. Proceedings of the joint CSCE-ASCE National Conference on Environmental Engineering, Montreal.

Gehr R, Wright H. 1998. UV disinfection of wastewater coagulated with ferric chloride: recalcitrance and fouling problems. Wat. Sci. Tech. 38 (3):15-23. 
Gschlöß1 T. 1994. UV disinfection of treated wastewater: possible effects on surface waters. Wat. Sci. Tech. 29 (12):255-266.

Harris GD, Adams VD, Sorensen DL, Dupont RR. 1987. The influence of photoreactivation and water quality on ultraviolet disinfection of secondary municipal wastewater. J. WPCF 59 (8):781-787.

James D, Truong M, Amy P, Steubing P, Lagadinos Tr Igbinovia A, Shumaker S, Cairns WL. 1996. Comparison of UV disinfecting technologies using low irradiance monochromatic and high irradiance polychromatic UV lamps, p.10-47. Proceedings of Specialty Conference: Disinfecting Wastewater for Discharge \& Reuse. WEF. Portland, OR.

Jenkins D, Hermanowicz SW. 1991. Principles of chemical phosphate removal, p. 91-110. In Sedlak R (ed.), Phosphorus and nitrogen removal from municipal wastewater. Lewis Publishers, Inc., New York.

Jesien W. 1998. Fouling of ultraviolet lamps during wastewater disinfection in pilot plant and full-scale applications. Master of Engineering Project Report \# G98-02, Department of Civil Engineering and Applied Mechanics, McGill University, Montreal.

Lidin RA, Andreeva LL, Molochko VA. 1995. Constants of inorganic substances: a handbook. Begel House, inc. New York. p. 221-280.

Lin L-S, Johnson CT, Blatchley III ER. 1997. Mechanisms of inorganic fouling at quartz:water interfaces in ultraviolet photoreactors, vol 1, p. 277-287. Proc. WEFTEC '97, Chicago, 1L.

Lin L-S, Johnson CT, Blatchley III ER. 1999. Inorganic fouling at quartz:water interfaces in ultraviolet photoreactors - II. Temporal and spatial distributions. Water Res. 33 (15):3330-3338.

Mishalani NR, Koester PA, Thyamagonadalu P. 1996. Effect of water quality on UV transmittance: the Burbank case study, p. 5:37-5:48. Proc. Specialty Conf.: Disinfecting Water for Discharge \& Reuse. WEF. Portland, OR.

Pankow JF. 1991. Aquatic chemistry concepts. Lewis Publishers, Inc., New York.

Perrot JY, Baron J. 1995. The disinfection of municipal wastewater by ultraviolet light: a French case study. Wat. Sci. Tech. 32 (7):167-174.

Schecher WD, McAvoy DC. 1994. MINEQL ${ }^{+}$: a chemical equilibrium program for personal computers: user's manual version 3.0. Environmental Research Software, Hallowell, ME.

Soroushian F, Noesen M, Jacques R, Tchobanoglous G. 1996. Impact of chemicals on reclaimed water disinfection, p. 10-15. Proceedings of Specialty Conference: Disinfecting Wastewater for Discharge \& Reuse. WEF. Portland, OR.

WEF. 1996. Wastewater disinfection: manual of practice. WEF. Alexandria, VA. 